\title{
GROUNDWATER POTENTIALS OF EOCENE LIMESTONE AQUIFER IN WEST-WEST EL-MINYA AREA, EGYPT
}

\author{
Sawsan M.M. Ibrahem ${ }^{*}$, Mohamed Elalfy ${ }^{2}$ and Mona A. Hagras ${ }^{3}$ \\ ${ }^{1}$ Department of Hydrology, Desert Research Center, El-Matareya, \\ Cairo, Egypt. \\ ${ }^{2}$ Khatib and Alami Company, Egypt \\ ${ }^{3}$ Department of Irrigation and Hydraulic, Faculty of Engineering, Ain \\ Shams University \\ *E-mail: sawsanmoselhy@yahoo.com
}

$\mathrm{T}$ he objective of this research is to estimate the groundwater potentials of the Eocene limestone aquifer through the application of GIS technique on the collected and measured data of the drilled wells. Through the investigation of 53 drilled wells, the depth to water increases from $70.8 \mathrm{~m}$ at south to $103.8 \mathrm{~m}$ at north. The groundwater flow direction is from east to west and from south to north. The salinity ranges from $1000 \mathrm{mg} / \mathrm{l}$ to $2982 \mathrm{mg} / \mathrm{l}$. The penetrated depth of the aquifer ranges between 175 $\mathrm{m}$ and $500 \mathrm{~m}$. The Eocene fractured limestone aquifer is considered as highly productive aquifer having transmissivity values of 99 $20160 \mathrm{~m}^{2} /$ day and attaining specific capacity values range between $<$ $18 \mathrm{~m}^{3} / \mathrm{h} / \mathrm{m}$ and $>300 \mathrm{~m}^{3} / \mathrm{h} / \mathrm{m}$. The geologic structures have a considerable effect on aquifer productivity due to increasing the fracture systems and caves. Geographic Information Systems (GIS) technique was applied as a tool to achieve the target of this study, where two scenarios were proposed. In scenario 1, the economic factor is the main factor in the process of extracting groundwater; the western and northeastern parts have the best priority representing $71.7 \%$ (100406 Feddan) of the investigated area. In scenario 2, the high productivity of groundwater is the influencing factor; the northern half of the study area and the southwestern corner have the high productivity zones representing about $60.8 \%$ (85058 Feddan) of the investigated area.

Keywords: Eocene, limestone, aquifer, specific capacity, potentials

Groundwater is the essential single fresh water source in many parts of the world during dry periods (Assaf and Saadeh, 2008). It is considered as the main source for agricultural activity, especially in the investigated area. 
Nowadays, Egypt pays attention for the new land reclamation projects to achieve self-sufficiency from strategic crops and to establish new settlements. West-West El-Minya area is considered one of the promising areas for future development plans in Egypt. No doubt, mismanagement exploitation and improper use of water policy will affect directly and/or indirectly both the quality and quantity of groundwater. Therefore, continuous investigation studies and generating groundwater potential maps in new reclamation areas are important for sustainable groundwater management. Such these studies are costly and time consuming and required a huge amount of data.

However, integration between GIS techniques and remote sensing with the available data of the drilled wells are employed recently in several studies to facilitate analyzing such these large volumes of required data and accelerate decision making for groundwater exploration. Andualem and Demeke (2019) used "weighted overlay analysis" to determine groundwater potential areas. Tolche (2020) generated a map using geospatial techniques which can be used in selecting sites for groundwater exploitation.

There are many factors affecting the groundwater potentials; such as depth to water, lithology, topography, land use and land cover, geological structures, lineaments, hydraulic parameters and water quality (Elewa and Qaddah, 2011 and Tolche, 2020), that is why results of studies of groundwater potentials based on the parameter taken into consideration are varied (Magesh et al., 2012).

In new reclamation land, such as West-West El-Minya, groundwater resources are used for irrigation and domestic utilities. Thus, a detailed study is required to identify the potential areas of groundwater resources for better investments.

The main objective of this research work is to construct of groundwater potential maps of the Eocene limestone aquifer as it is considered as the essential aquifer in the investigated area in West-West ElMinya, which is considered as a part of the great project for reclaiming a million and a half million Feddan $\left(1\right.$ Feddan $\left.=4200 \mathrm{~m}^{2}\right)$ depending on its groundwater resource for reclamation.

To achieve this objective, the collected hydrogeological data of 53 wells including; depth to water, total drilled depth, depth to top surface of limestone aquifer, water salinity and data of pumping tests will be analyzed to assess the aquifer potentials.

Four determinant factors, namely, depth to the top surface of Eocene limestone aquifer, specific capacity, full recovery time and the expected dynamic water level were accounted for in the study.

Many researchers conducted investigation studies in the Eocene limestone aquifer at the desert fringes of west El-Minya governorate among them; El-Kashouty (2010), El-Kashouty et al. (2012), Ibrahim (2013), El- 
Deeb et al. (2015), Abdel Moneim et al. (2016), Ibrahim and Lyons (2017), and Gedamy et al. (2019).

\section{LOCATION OF THE STUDY AREA}

The study area lies to the west of the Nile Valley occupying the area between latitudes $28^{\circ} 10^{\prime} 00^{\prime \prime}$ and $28^{\circ} 30^{\prime} 00^{\prime \prime} \mathrm{N}$, and longitudes $29^{\circ} 48^{\prime} 00^{\prime \prime}$ and $30^{\circ} 42^{\prime} 36^{\prime \prime} \mathrm{E}$ (Fig. 1). El-Minya governorate area is characterized by arid to semi-arid climate, hot, dry, and rainless in summer, and mild with rare precipitation in winter. The average temperatures during January are $4.6^{\circ} \mathrm{C}$ to $20.5^{\circ} \mathrm{C}$ and $20.5^{\circ} \mathrm{C}$ to $37.7^{\circ} \mathrm{C}$ during August. The annual rainfall value is about $19.6 \mathrm{~mm} /$ year (Salem, 2015). So, the input of rainfall to groundwater recharge is limited (Yousif et al., 2018). Evaporation in "ElMinya governorate" ranges from $14.85 \mathrm{~mm} / \mathrm{month}$ in June to 3.54 $\mathrm{mm} / \mathrm{month}$ in December, with the average value of $8.92 \mathrm{~mm} / \mathrm{month}$ and total amount of about $107.04 \mathrm{~mm} /$ year. Evapotranspiration at El-Minya is $4897.91 \mathrm{~mm} /$ year (Korany, 1980 and 1984). The mean monthly relative humidity during daytime according to "Egyptian Meteorological Authority" has average value of $54.76 \%$ (Elewa et. al, 2013).

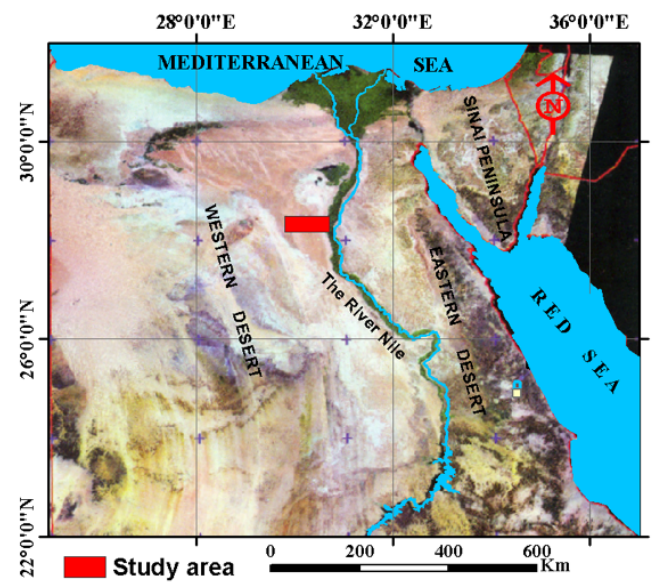

Fig. (1). Location map of the study area.

\section{GEOMORHOLOGICAL AND GEOLOGICAL SETTING}

The Nile River channel runs between two high calcareous plateaus bounding it from east and west with a gentle slope from south to north with about $0.1 \mathrm{~m} / \mathrm{km}$ (Korany et al., 2008). The Nile tends to represent the eastern part of the Valley; therefore, the cultivated area is wider in the western part than in the east. According to Shabana (2010), the study area includes the following three geomorphologic units: 
1-Young alluvial plain of the Nile: It occupies the area adjacent to the Nile bank from west to the eastern scarp of the limestone plateau.

2- Nile terraces: They lay adjacent to the cliff of the limestone plateau and to the west of the young alluvial plain forming a gently undulated dissected surface made of several broad benches differentiated into old and young terraces.

3- Western limestone plateau: This bounds the Nile Valley from the east and the west. Generally, the ground elevation varies widely from $20 \mathrm{~m}$ in the flood plain area to $200 \mathrm{~m}$ at the limestone plateau at west. Thus, the general slope is from the western plateau toward the floodplain of the Nile Valley as clear from the Digital Elevation Model (Fig. 2).

Geologically, the surface of the study area is covered by the Middle Eocene limestone, Oligocene-Pleistocene gravel and sand and Quaternary deposits (Fig. 3).

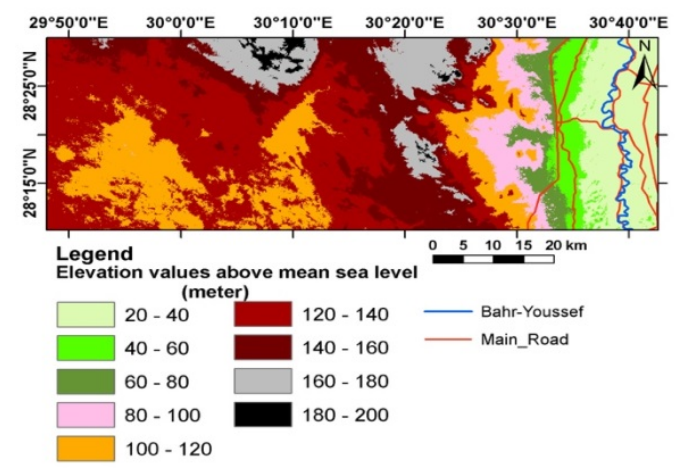

Fig. (2). Digital Elevation Model (DEM) of the study area.

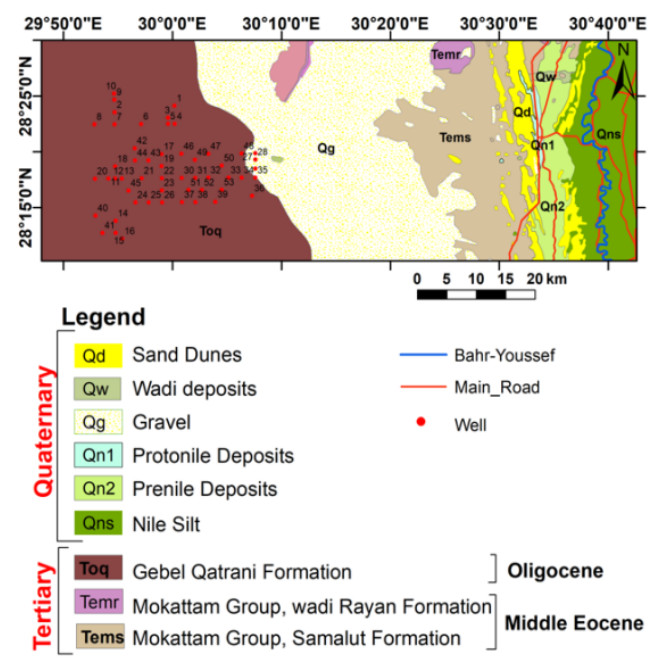

Fig. (3). Regional geologic map of the study area (CONOCO, 1987).

Egyptian J. Desert Res., 70, No. 1, 59-82 (2020) 
According to Shabana (2010), the recorded rock units from base to top are:

\section{Middle Eocene limestone (Samalut Formation)}

Samalut Formation is the oldest exposed rock unit in the study area overlying El-Minya Formation of Lower Eocene. It consists mainly of massive limestone assigned to the Early-Middle Lutetium times. This Formation is exposed at eastern portion, while in the western portion; it is covered by a great thickness of Oligocene-Pleistocene gravels and sands. Samalut Formation represents one of the main water bearing formations in the study area.

\section{Oligocene-Pleistocene gravel and sand}

It covers a wide area and composed mainly of gravel, sand, clay, and limestone fragments.

\section{Quaternary deposits}

It has a wide distribution in the eastern side including the Nile silt, sand dunes and fanglomerates.

Structurally, the Nile Valley is essentially bounded by wrench faults that are more or less parallel either to NW-SE trend of the Gulf of Suez or to NE-SW trend of Gulf of Aquba (Youssef, 1968 and Shabana, 2010).

\section{RESULTS AND DISCUSSION}

\section{Aquifer Systems}

The available and field data of 53 wells (Fig. 4) tapping only the fractured limestone aquifer of the Middle Eocene (Samalut Formation) were used to carry out the current study. These data include well drilling data collection, water level measurements, long duration and recovery tests and water sampling. It was found that the aquifers in the study area fall into two categories: unconsolidated aquifer (granular) represented by the Oligocene aquifer and consolidated fractured aquifer represented by the Eocene fractured limestone aquifer of secondary porosity.

Due to the nature of complicated fracture system in fractured rock aquifers and their heterogeneity, there is a difficulty to be investigated. The groundwater flow is classified as non-Darcian flow in this hydrological system. The present work focuses only on the Middle Eocene limestone aquifer.

\subsection{Hydrogeological cross-sections}

The lateral and vertical extensions of the Eocene aquifer are shown through 6 hydrogeological cross-sections (Fig. 5 and 6). Three of them (A$\mathrm{A}^{\prime}, \mathrm{B}-\mathrm{B}^{\prime}$ and $\left.\mathrm{C}-\mathrm{C}^{\prime}\right)$ are crossing the study area in West-East direction and the other three (D-D', E-E' and F-C') have North-South direction. To avoid any repetitions in the description of these cross-sections the following features are distinguished: 
West-East hydrogeological cross-sections:

1- These cross-sections include A-A', B-B' and $\mathrm{C}^{-} \mathrm{C}^{\prime}$ having West-East direction. The lengths of these cross-sections are $12 \mathrm{~km}, 24 \mathrm{~km}$ and 24 $\mathrm{km}$, respectively.

2- The cross-sections $\mathrm{A}-\mathrm{A}^{\prime}, \mathrm{B}-\mathrm{B}^{\prime}$ and $\mathrm{C}^{-} \mathrm{C}^{\prime}$ pass from the west to the east through wells Nos. $(8,7,6,5$ and 4), (20, 11, 13, 21, 22, 30, 31, 32, 33, 34 and 35 ) and (40, 24, 25, 26, 37. 38, 39 and 36), respectively (Fig. 5).

3 - The total drilling depth of the wells along these cross-sections ranges between $500 \mathrm{~m}$ (wells 22, 31 and 32, section B-B') and $705 \mathrm{~m}$ (well 39,

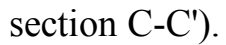

4- The two aquifers; the Oligocene aquifer which composes of sand, gravel and clay and the Eocene aquifer which composes of fractured and caved limestone are water bearing formations along these sections.

5- Water depth ranges from $72.5 \mathrm{~m}$ (well 13, cross-section B-B') to $103.8 \mathrm{~m}$ (well 5, cross-section A-A').

6- Thickness of Oligocene aquifer ranges betwee $46.4 \mathrm{~m}$ (well 4, crosssection $\mathrm{A}-\mathrm{A}^{\prime}$ ) and $253.8 \mathrm{~m}$ (well 40 cross-section C-C').

7- The depth to Eocene limestone aquifer varies from $120 \mathrm{~m}$ (well 13, crosssections B-B') to $335 \mathrm{~m}$ (well 40, cross-section C-C').

8- The minimum recorded pentrated thickness of Eocene limestone aquifer is $239 \mathrm{~m}$ at well 32 (cross-section A-A'), while the maximum one is 480 $\mathrm{m}$ at well 13 (cross-section B-B').

9- Water salinity of Eocene limestone aquifer ranges between $1888 \mathrm{mg} / \mathrm{l}$ at well 11 (cross-section B-B') and $2790 \mathrm{mg} / 1$ at well 25 (cross-section C$\left.\mathrm{C}^{\prime}\right)$.

10- The West-East cross-sections are influenced by three normal faults in NW-SE and NE-SW directions. These faults are F15 at cross-section AA', F6 at cross-section B-B' and F4 and F6 at cross-section C-C'. These faults are making hydraulic connection between the Oligocene (gravel and sand) and Eocene (fractured limestone) aquifers through fault rising. This fault rising brought the Eocene fractured limestone aquifer at the upthrown sides of these faults in juxtaposition with the Oligocene aquifer at the downthrown sides.

North-South hydrogeological cross-sections:

1- These cross-sections include D-D', E-E' and F-C' having North-South direction. The lengths of these cross-sections are $24.5 \mathrm{~km}, 16.4 \mathrm{~km}$ and $7.1 \mathrm{~km}$, respectively.

2- The cross-sections D-D', E-E' and F-C' pass from the north to the south through wells Nos. (10, 9, 2, 7, 18, 12, 14, 15 and 16), (1, 3, 5, 17, 19, 22, 23 and 26) and (27, 28, 29, 35 and 36), respectively (Fig. 6).

3 - The total drilling depth of the wells along these cross-sections ranges between $500 \mathrm{~m}$ (well 22, cross-section E-E') and $700 \mathrm{~m}$ (well 36, crosssection $\mathrm{F}-\mathrm{C}^{\prime}$ ).

Egyptian J. Desert Res., 70, No. 1, 59-82 (2020) 
4- Along these cross-sections, the Oligocene and the Eocene aquifers are existed.

5- Water depth ranges from $70.8 \mathrm{~m}$ (well 23) to $103.8 \mathrm{~m}$ (well 5) on crosssection E-E'.

6- Thickness of Oligocene aquifer ranges betwee $40.5 \mathrm{~m}$ (well 18, crosssection $\mathrm{D}^{\left.-\mathrm{D}^{\prime}\right)}$ and $223.4 \mathrm{~m}$ (well 36 cross-section F-C').

7- The depth to Eocene limestone aquifer varies from $112 \mathrm{~m}$ (well 18, cross-section D-D') to $320 \mathrm{~m}$ (well 36, cross-section F-C').

8- The minimum recorded pentrated thickness of Eocene limestone aquifer is $255 \mathrm{~m}$ at well 15 (cross-section D-D'), while the maximum one is 500 $\mathrm{m}$ at well 10 (cross-section D-D').

9- Water salinity of Eocene limestone aquifer ranges between $1000 \mathrm{mg} / \mathrm{l}$ at well 14 (cross-section D-D') and $2656 \mathrm{mg} / \mathrm{l}$ at well 26 (cross-section EE').

10- The North-South hydrogeological cross-sections are influenced by eight normal faults in NW-SE and NE-SW directions. These faults are; F12, F1, F2, F13, F4 and F14 at cross-section D-D', F7 at cross-section E-E' and F11 at cross-section F-C'.

11- The existed faults as shown along these cross-sections are making hydraulic connection between Oligocene sand and gravel and the underlying Eocene fractured limestone aquifers as mentioned in the West-East cross-sections.

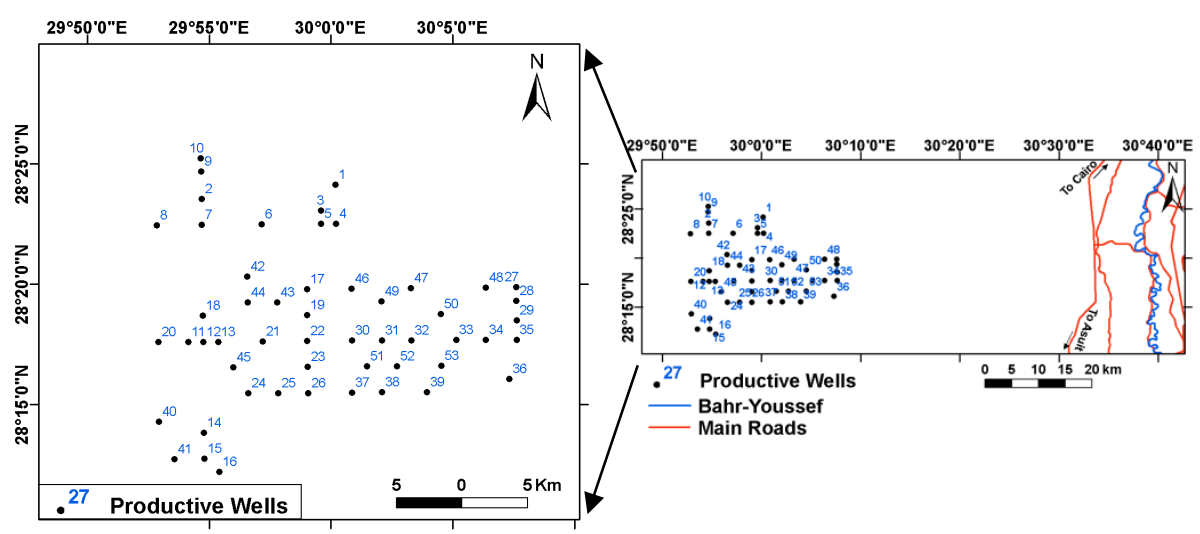

Fig. (4). Well location map. 


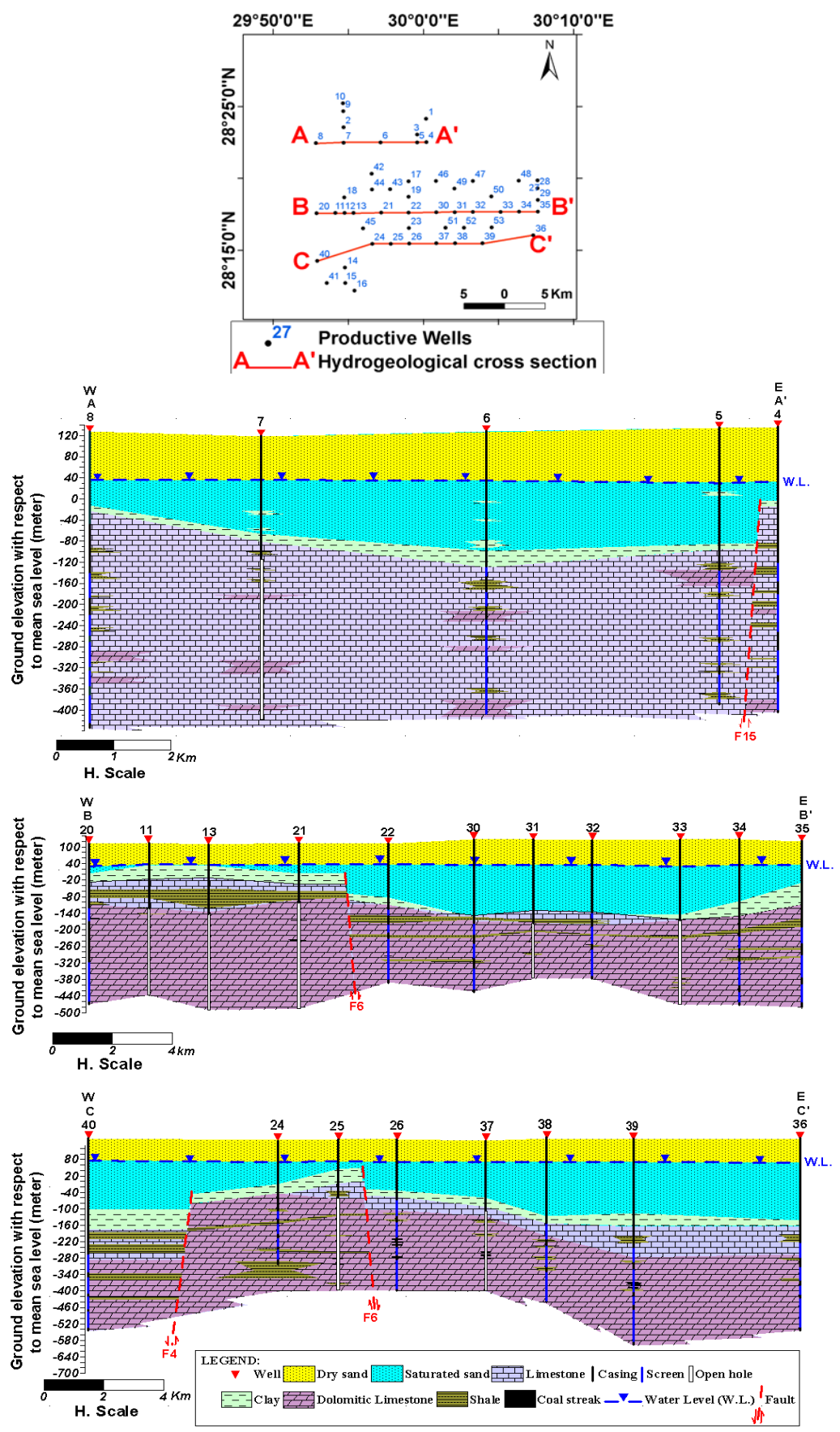

Fig. (5). Hydrogeological cross-sections A-A', B-B' and C-C'.

Egyptian J. Desert Res., 70, No. 1, 59-82 (2020) 

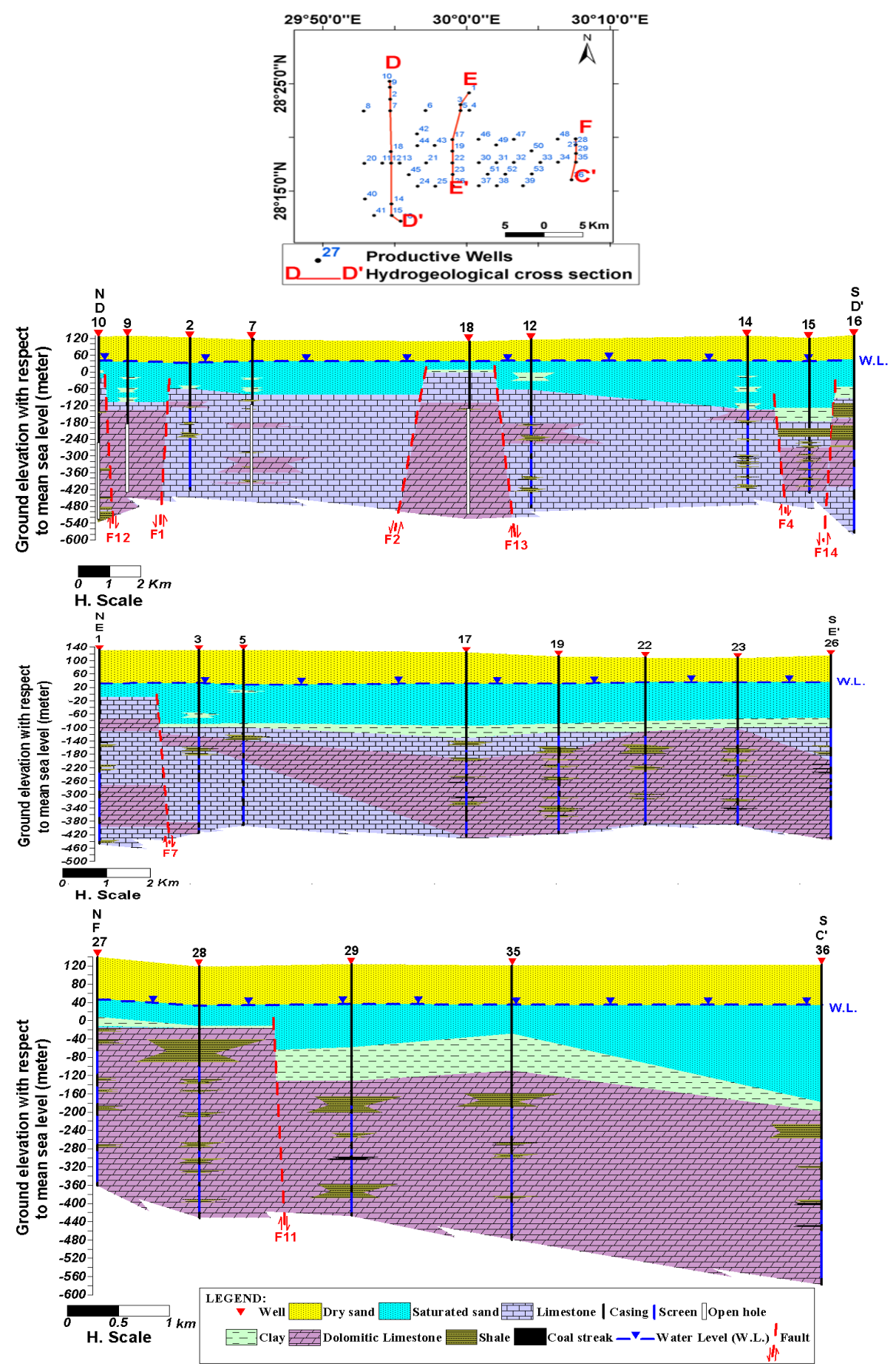

Fig. (6). Hydrogeological cross-sections D-D', E-E' and F-C'.

Egyptian J. Desert Res., 70, No. 1, 59-82 (2020) 


\subsection{Groundwater movement}

The groundwater movement in the study area is discussed through the thematic raster maps representing the distribution of the depth to water and the potentiometric surface (Fig. 7a and b). The water depth is an important parameter for the groundwater pumping and the drilling depth. The depth to water map (Fig. 7a) illustrates that the water depth increases northward from $70.8 \mathrm{~m}$ (well 23) at the south to $103.8 \mathrm{~m}$ (well 5) at the north. On the other hand, the potentiometric surface, with respect to the mean sea level, ranges between $28.3 \mathrm{~m}$ at well 33 and $48.5 \mathrm{~m}$ at well 27 with general decrease westward (Fig. 7b). The general groundwater flow as shown on the potentiometric contour map (Fig. 7c) is from the east to the west and from the south to the north with some exceptions. These exceptions are represented by the cone of depressions at wells 2, 5 and 33 .

\subsection{Penetrated thickness}

The distribution of the partially penetrated saturated thickness of the Eocene limestone aquifer as shown on the thematic raster map (Fig. 8) indicates that the penetrated aquifer thickness decreases from the all directions to the center of the study area at well $46(175 \mathrm{~m})$ and reaches its maximum thickness at well $10(500 \mathrm{~m})$. Accordingly, it is recommended to penetrate the full thickness of the aquifer to increase the productivity of the wells.

\subsection{Water salinity}

The spatial distribution of the total dissolved solids (TDS) of the Eocene limestone aquifer (Fig. 9) illustrates that the TDS varies from 1000 $\mathrm{mg} / \mathrm{l}$ at well 14 at the southwestern part of the study area to $2982 \mathrm{mg} / \mathrm{l}$ at well 45. In general, the dominant TDS value is more than $2000 \mathrm{mg} / \mathrm{l}$ covering $96.9 \%$ of the study area.

\section{The Role of the Geologic Structures on the Occurrences of Groundwater}

The geologic structures have a direct effect on the groundwater occurrences. Via the drilled wells data, it was found that the upper surface of the Eocene limestone aquifer was considered as a marker bed to demonstrate the geologic structures according to the level of this aquifer. Accordingly, two thematic raster maps (Fig. 10a and b) were constructed to illustrate the depth to the upper surface of the Eocene limestone aquifer and its level referenced to Mean Sea Level with the predicted inferred faults that have a direct impact on the groundwater occurrences and the hydraulic connection between this aquifer and the overlying Oligocene aquifer. 


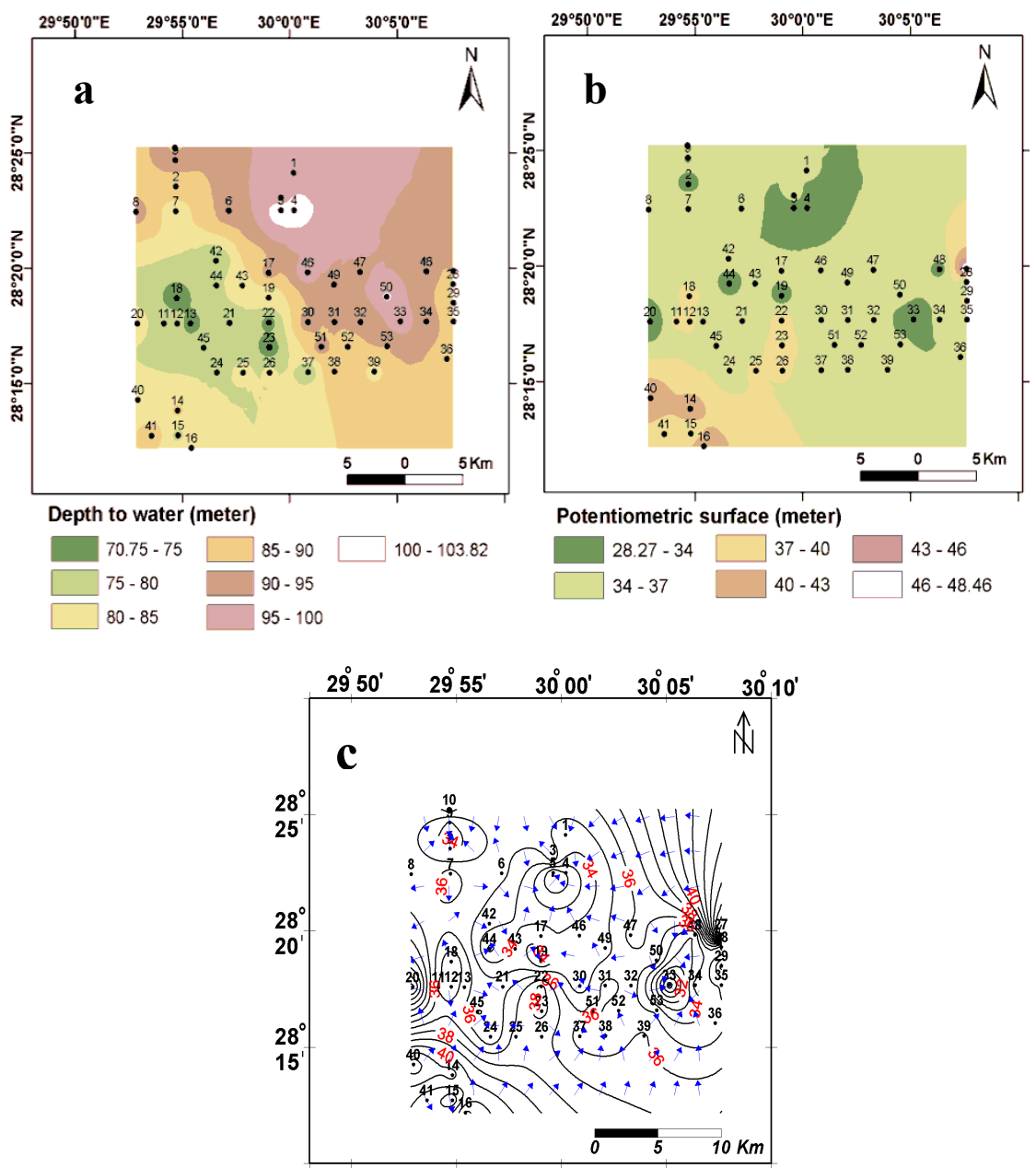

Fig. (7). Maps showing: (a). depth to water (m), (b). potentiometric surface with respect to Mean Sea Level $(\mathrm{m})$ and $(\mathbf{c})$. potentiometric contour map (m). 


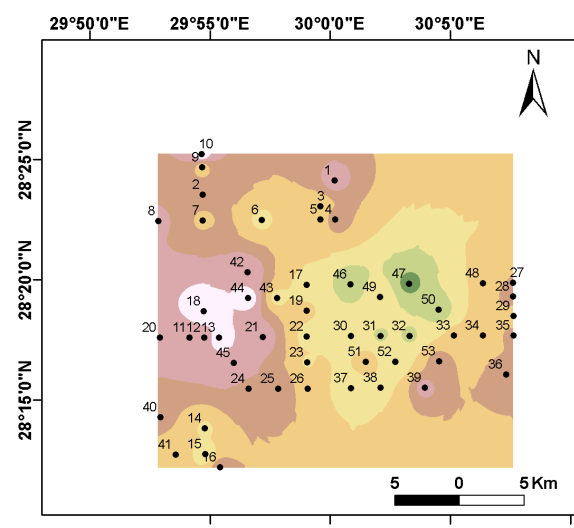

Penetrated thickness of Eocene aquifer (meter)

\begin{tabular}{|c|c|c|}
\hline $175-200$ & $300-350$ & $450-500$ \\
\hline $200-250$ & $350-400$ & \\
\hline $250-300$ & $400-450$ & \\
\hline
\end{tabular}

Fig. (8). Penetrated thickness of Eocene aquifer (m).

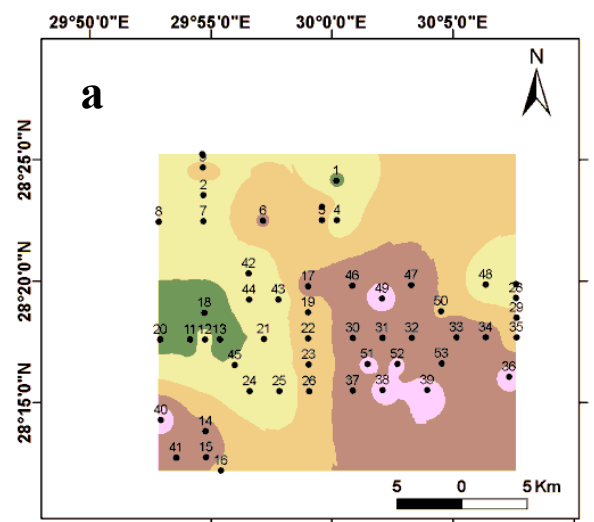

Depth to the top surface of Eocene Limestone aquifer

$$
\text { (meter) }
$$

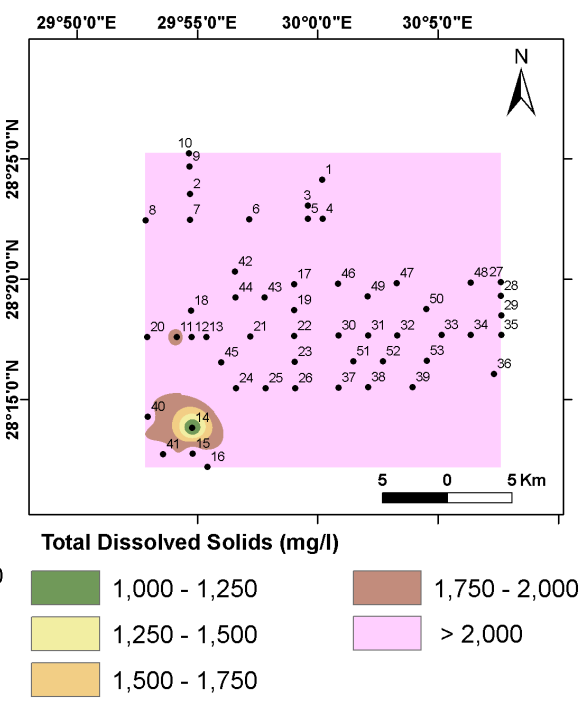

Fig. (9). Total dissolved solids (mg/l).
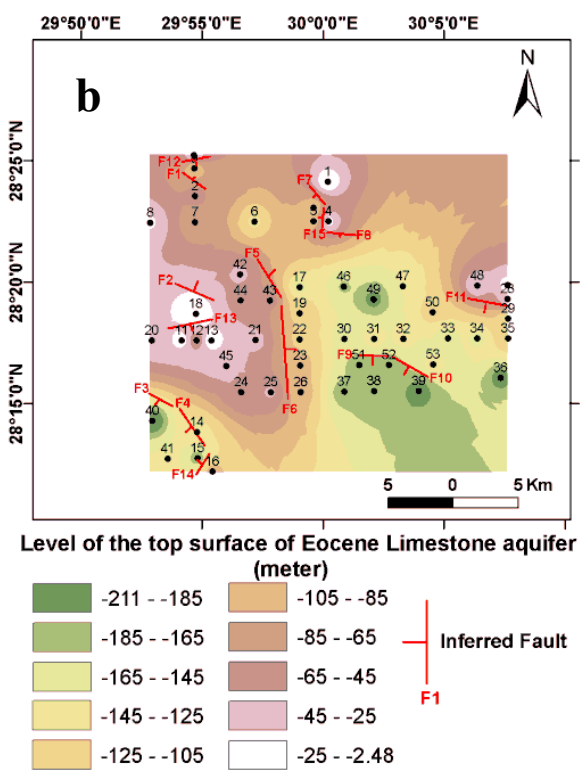

Fig. (10). Maps showing: (a). depth to the top surface of Eocene Limestone aquifer ( $\mathrm{m}$ ) and (b). Level of the top surface of Eocene Limestone aquifer (m) with inferred faults

Egyptian J. Desert Res., 70, No. 1, 59-82 (2020) 


\subsection{Depth to the upper surface of the Eocene limestone aquifer}

The constructed depth to the upper surface of the Eocene limestone aquifer map (Fig. 10a) shows that, approximately, the depth values range between 250 and $335 \mathrm{~m}$ in the east and the southwestern corner of the study area while the depth values range between 112 and $250 \mathrm{~m}$ in the west of the study area.

\subsection{Level of upper surface of Middle Eocene limestone aquifer}

Figure (10b) illustrates that the level of the upper surface of the Eocene limestone aquifer referenced to the Mean Sea Level varies from $2.5 \mathrm{~m}$ at well 18 to $-211 \mathrm{~m}$ at well 40 with general dipping to the central part at well 49 and to the southwestern corner at well 40 . This map helps in detection of the inferred faults that affected the study area and contribute to the hydraulic connection between the Oligocene and Eocene fractured limestone aquifers.

\subsection{Inferred faults}

There are 15 normal faults forming grabens and horsts affect the study area (Fig. 10b). The faults Nos. 1-12 have NW-SE trend, while the faults Nos. 13-15 have NE-SW trend. These faults have a great role in the occurrence of the groundwater and the hydraulic connection with the overlying Oligocene aquifer.

\section{Aquifer Hydraulic Characteristics}

It is especially important to provide information about aquifer hydraulic parameters such as specific capacity, transmissivity, full recovery time and the expected dynamic water level, which help in understanding the aquifer potentials. Pumping test is an effective tool to achieve this target. In the present work, constant discharge pumping and recovery tests were carried out for the investigated wells. The results obtained from these tests are represented by four thematic raster maps (Fig. 11a, b, c, and d) as follows:

\subsection{Specific capacity}

Specific capacity of a well is a measure of both the productivity of a well and the aquifer transmissivity. It is defined as the ratio of pumping rate and the drawdown (Summers, 1972). For the Eocene fractured limestone aquifer (heterogeneous system) in the investigated area, it was found that the specific capacity $(\mathrm{Q} / \mathrm{s})$ ranges between less than $18 \mathrm{~m}^{3} / \mathrm{h} / \mathrm{m}$ and more than $300 \mathrm{~m}^{3} / \mathrm{h} / \mathrm{m}$. According to Sen (1995), the aquifer is classified as highly productive aquifer except the western area with specific capacity values less than $18 \mathrm{~m}^{3} / \mathrm{h} / \mathrm{m}$ which considered as moderately productive as shown on Figure 11a. 

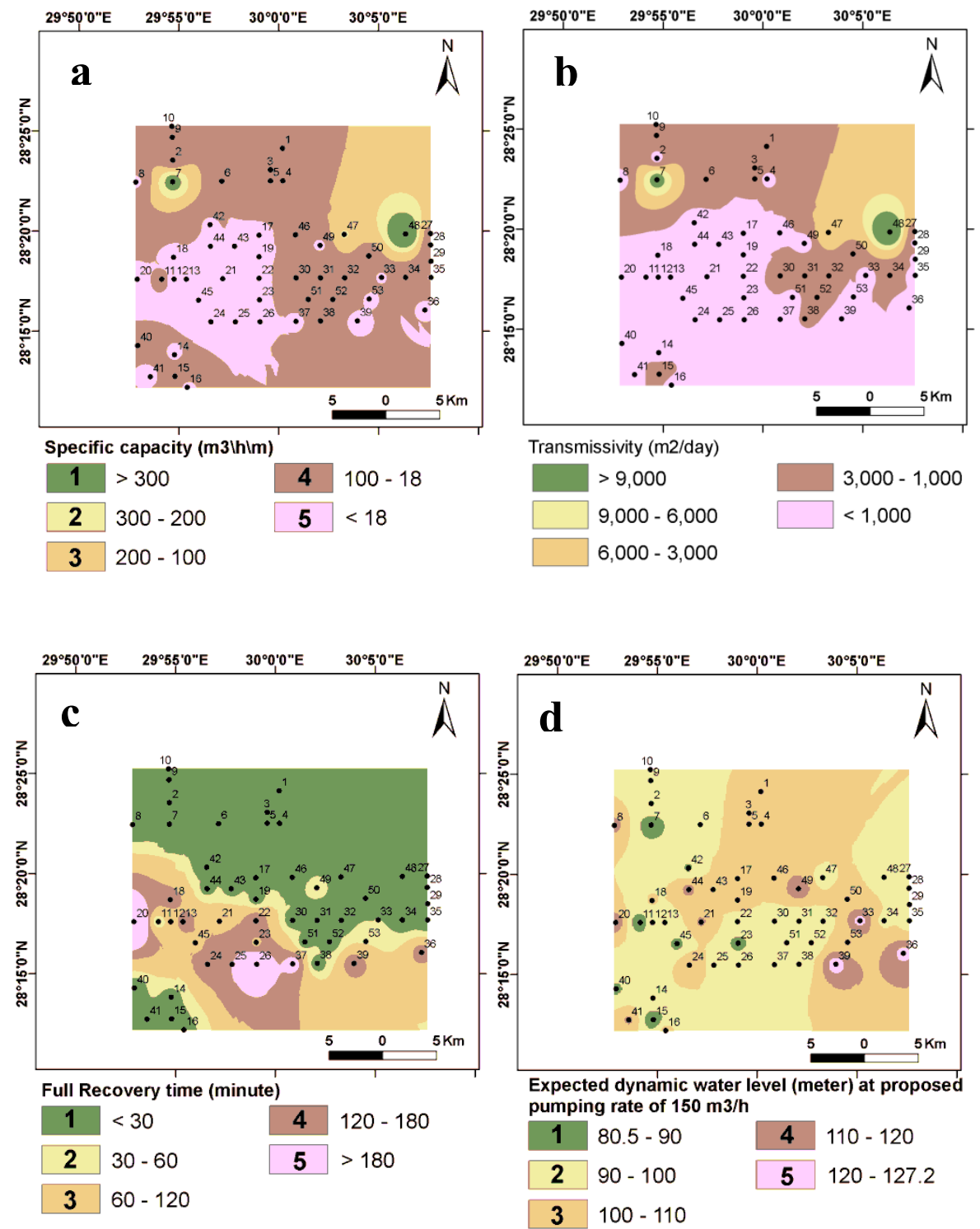

Fig. (11). Maps showing (a). specific capacity $\left(\mathrm{m}^{3} / \mathrm{h} / \mathrm{m}\right)$, (b). transmissivity $\left(\mathrm{m}^{2} /\right.$ day), (c). full recovery time (minute) and (d). the expected dynamic water level (m) of Eocene Limestone aquifer.

Egyptian J. Desert Res., 70, No. 1, 59-82 (2020) 


\subsection{Transmissivity}

Transmissivity for the Eocene fractured aquifer can be estimated by the following equation (Verbovsek, 2008).

where

$$
\mathbf{T}=\mathbf{C}(\mathbf{Q} / \mathbf{s})
$$

$\mathrm{T} \quad$ is the transmissivity $\mathrm{m}^{2} /$ day

$\mathrm{Q} / \mathrm{s}$ is the specific capacity $\mathrm{m}^{3} / \mathrm{day} / \mathrm{m}$

$\mathrm{C}$ is constant value and is found to vary from 0.9 to 1.5 with an average of 1.2 (Jalludin and Razack, 2004) or 1.22 (Misstear, 2001).

The approximated transmissivity values for the Eocene fractured aquifer range between less than $1000 \mathrm{~m}^{2}$ /day in the southern part, while in the northern part it is more than $9000 \mathrm{~m}^{2} /$ day as shown in Fig. (11b).

\subsection{Full recovery time}

Full recovery time and rate of recovery were monitored to assess the response of the pumped well after the pump has been shut down via measuring the rise of water level in the pumped well after the pumping test has been completed and the pump is turned off in what is known as a recovery test.

The inspection of the thematic raster map of the full recovery time (Fig. 11c) and the representation of the field measurement data in Fig. (12), where the residual drawdown $\left(\Delta s^{\prime}\right)$ values are plotted against their corresponding $\mathrm{t} / \mathrm{t}$ ' on a single logarithmic scale, reveals that the time taken to achieve complete recovery of the drawdown and reach to the original static water level in the wells ranges between less than $30 \mathrm{~min}$ in wells Nos. 7 ( 2 minutes), 15 (4 minutes) and 48 (5 minutes) and more than $180 \mathrm{~min}$ in well No. 20 (540 minutes) as representative wells. The small values of the full recovery time for the fractured aquifer (Eocene fractured limestone) is attributed to the nature of the karst aquifers, which have multiple types of porosity and two flow types of water: laminar and turbulent flows. The laminar flow occurs within the matrix domain of the karst aquifer with slow velocities and the turbulent flow occurs in the large diameter void spaces that are well connected forming conduit domain with high permeability and fast water movement.

\subsection{Dynamic water level}

Dynamic water level is the level of water in the productive well during pumping. In the present study, the expected dynamic water level at constant rate of pumping of order $150 \mathrm{~m}^{3} / \mathrm{h}$ is calculated using the data of specific capacity. The thematic layer of the expected water level is constructed and classified into five classes with values lie between $80.5 \mathrm{~m}$ at well No. 15 up to $127.2 \mathrm{~m}$ at well No. 39 as shown in Fig. (11d). 


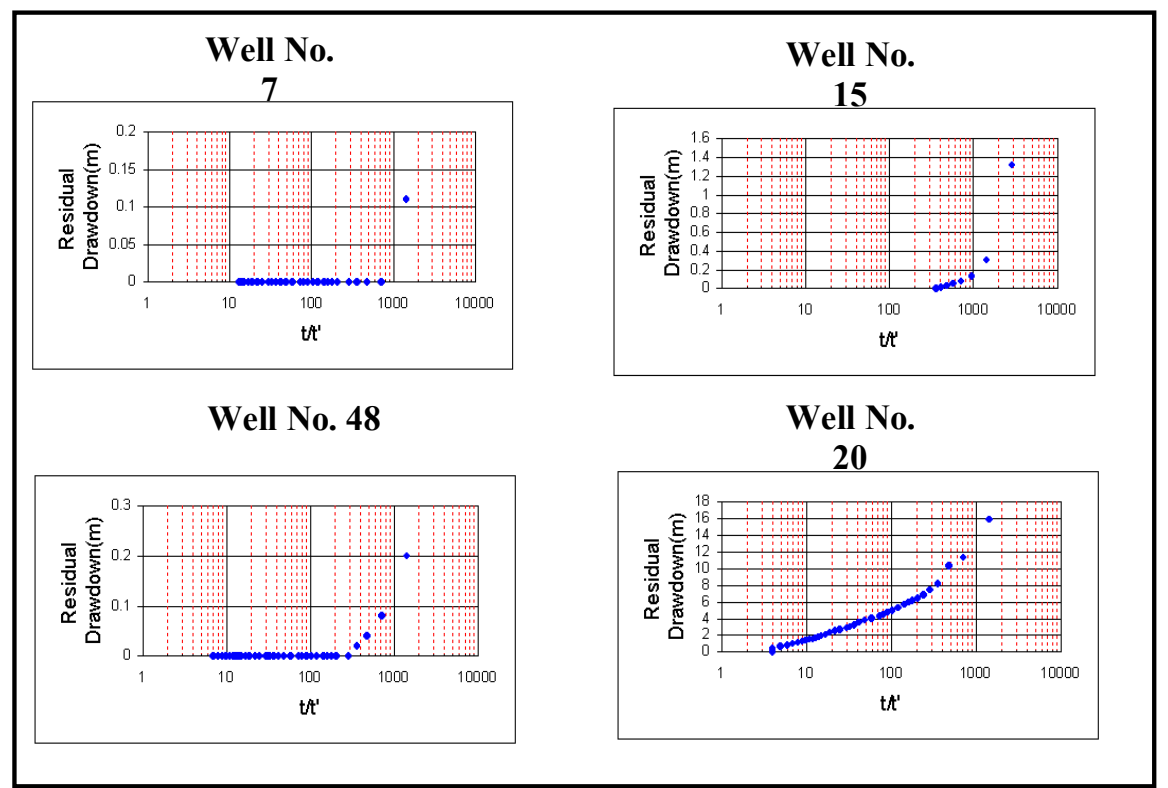

Fig. (12). Recovery test data for some representative wells of Eocene Limestone aquifer.

\section{Aquifer Potentials}

In this work, the main target is to provide a priority map reflecting the groundwater potentials of the Eocene fractured limestone aquifer for water investments on the scale of the investigated area. The Geographic Information Systems (GIS) technique was applied as a tool to achieve this target. First step is the creation of the different GIS layers represented as thematic raster layers of the aquifer characteristics as shown in Fig. (7, 8, 9, 10 and 11) using the "ArcMap software version 9.2" (ESEI, 2006). Four thematic raster layers were selected representing the most effective parameters in the groundwater potentials covering the different requirements and needs of investors as shown on the flow chart (Fig. 13). These layers are; the depth to the top surface of Eocene limestone aquifer (m) (Fig. 10a), specific capacity $\left(\mathrm{m}^{3} / \mathrm{h} / \mathrm{m}\right)$ (Fig. 11a), full recovery time (minute) (Fig. 11c) and the expected dynamic water level (m) (Fig. 11d). The second step is reclassifying the classes to give them values from best to worst (values from 1-5) in the four selected layers. Raster calculation between these layers was processed with a specific weight for each layer according to its importance in the groundwater investments through two proposed different scenarios. The result of the calculations of these layers is a priority map with five priority classes for each scenario indicating aquifer potentials classified to five classes, ("Excellent", "Very good", "Good", "Moderate" and "Poor"), in the study area. 


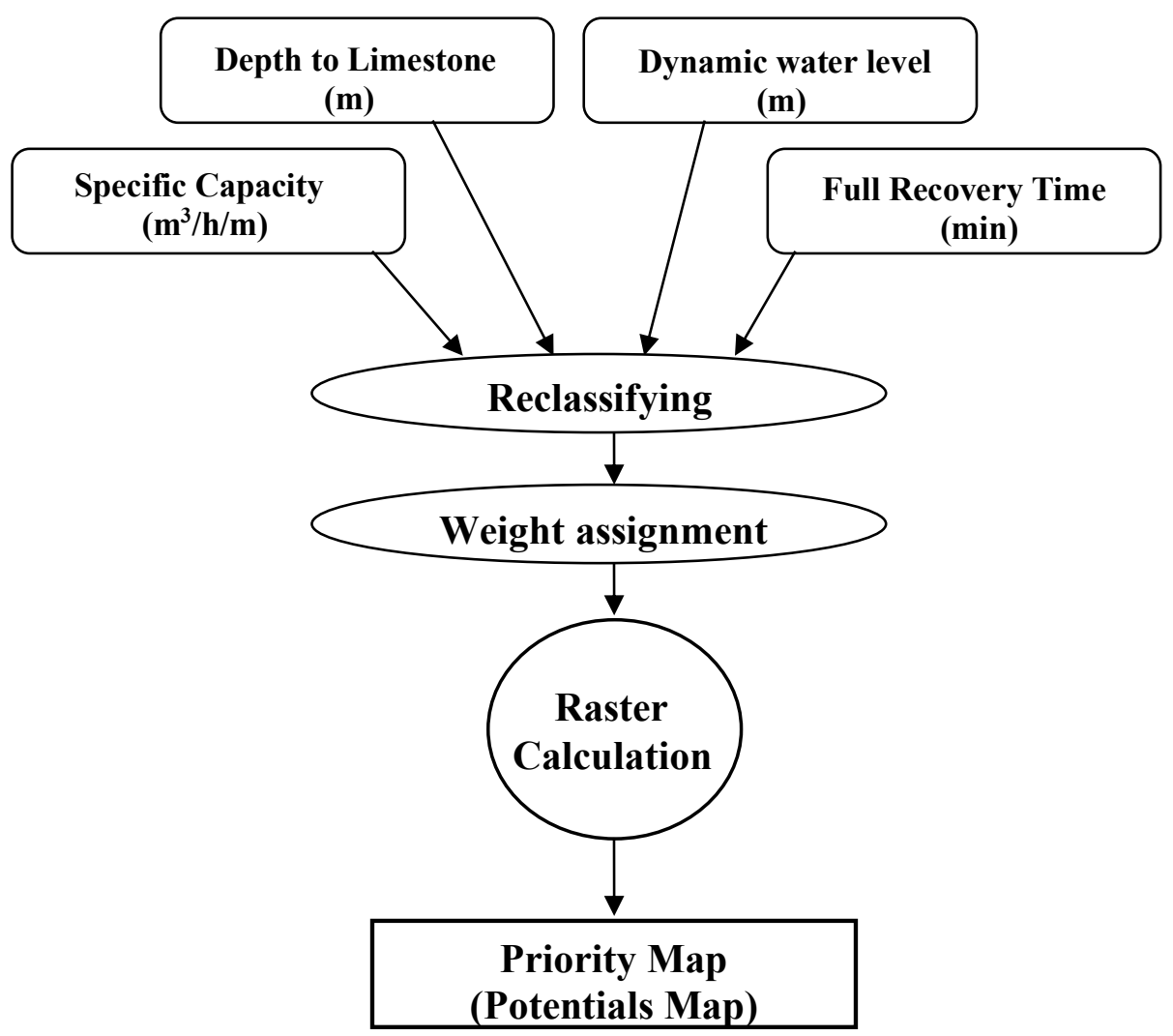

Fig. (13). Flow chart shows the input and the output of the raster calculation.

\subsection{Scenario 1}

In this scenario, the economic factor is the dominant factor, i.e. the low cost of groundwater extraction is the need of the investors. So, the depth to the top surface of the Eocene limestone aquifer is important factor because it controls the depth of drilling and it can be translated to money. Also, the expected dynamic water level in the productive well is an economic factor because it means power consumption. These two thematic layers take the highest weights $(40 \%$ for each of the depth to the top surface of the Eocene limestone aquifer and the expected dynamic water level out of $100 \%$ of the four layers). On the hand, the specific capacity and full recovery time take low weights $(10 \%$ for each layer out of the $100 \%$ of the four layers). The result is a final model map with five priorities for the groundwater investments (Fig. 14a, Scenario 1). The characteristics of the areas covering each priority can be summarized in Table (1). 

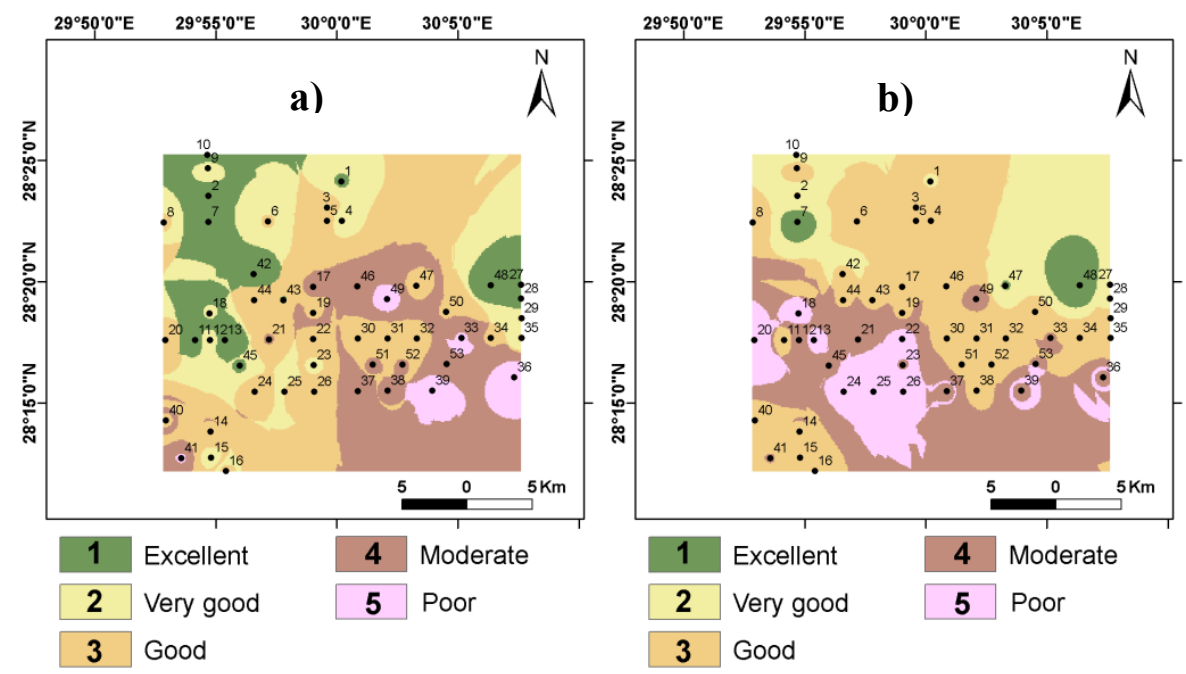

Fig. (14). The spatial distribution of the groundwater potentials of the Eocene limestone aquifer in two different scenarios; (a). Scenario 1 and (b). Scenario 2.

Table (1). Regional characteristics of the areas covering each priority (Scenario 1).

\begin{tabular}{|c|c|c|c|c|c|c|}
\hline \multirow{3}{*}{ Layer name } & \multirow{3}{*}{$\begin{array}{c}\text { Weight value } \\
(\%)\end{array}$} & \multicolumn{5}{|c|}{ Range of each layer in the final model map } \\
\hline & & Priority 1 & Priority 2 & Priority 3 & Priority 4 & Priority 5 \\
\hline & & Excellent & Very Good & Good & Moderate & Poor \\
\hline $\begin{array}{c}\text { Depth to } \\
\text { limestone (m) }\end{array}$ & 40 & $\begin{array}{c}\text { Classes } \\
\mathbf{1 , 2} \\
112-200\end{array}$ & $\begin{array}{c}\text { Classes } \\
\mathbf{1 , 2 , 3 , 4} \\
112-300\end{array}$ & $\begin{array}{c}\text { Classes } \\
\mathbf{2 , 3 , 4} \\
150-300\end{array}$ & $\begin{array}{c}\text { Classes } \\
\mathbf{4 , 5} \\
250-335\end{array}$ & $\begin{array}{c}\text { Classes } \\
\mathbf{4 , 5} \\
250-335\end{array}$ \\
\hline $\begin{array}{c}\text { Expected } \\
\text { dynamic water } \\
\text { level }(\mathrm{m})\end{array}$ & 40 & $\begin{array}{c}\text { Classes } \\
\mathbf{1 , 2} \\
80.5-100\end{array}$ & $\begin{array}{c}\text { Classes } \\
\mathbf{1 , 2 , 3} \\
80.5-110\end{array}$ & $\begin{array}{c}\text { Classes } \\
\mathbf{2 , 3 , 4} \\
90-120\end{array}$ & $\begin{array}{c}\text { Classes } \\
\mathbf{2 , 3 , 4} \\
90-120\end{array}$ & $\begin{array}{c}\text { Classes } \\
\mathbf{4 , 5} \\
110-127.5\end{array}$ \\
\hline $\begin{array}{l}\text { Specific } \\
\text { capacity } \\
\left(\mathbf{m}^{3} / \mathbf{h} / \mathbf{m}\right)\end{array}$ & 10 & $\begin{array}{c}\text { Classes } \\
\mathbf{1 , 2 , 3 , 4 , 5} \\
>300-<18 \\
\text { whole range }\end{array}$ & $\begin{array}{c}\text { Classes } \\
\mathbf{3 , 4 , 5} \\
200-<18\end{array}$ & $\begin{array}{c}\text { Classes } \\
\mathbf{3 , 4 , 5} \\
200-<18\end{array}$ & $\begin{array}{c}\text { Classes } \\
\mathbf{4 , 5} \\
100-<18\end{array}$ & $\begin{array}{c}\text { Classes } \\
\mathbf{4 , 5} \\
100-<18\end{array}$ \\
\hline $\begin{array}{l}\text { Full recovery } \\
\text { time (min) }\end{array}$ & 10 & $\begin{array}{c}\text { Classes } \\
\mathbf{1}, \mathbf{2}, \mathbf{3}, \mathbf{4} \\
<30-180\end{array}$ & $\begin{array}{c}\text { Classes } \\
\mathbf{1 ,}, \mathbf{3}, \mathbf{4} \\
<30-180\end{array}$ & $\begin{array}{c}\text { Classes } \\
\mathbf{1 , 2 , 3 , 4 , 5} \\
<30->180 \\
\text { Whole range }\end{array}$ & 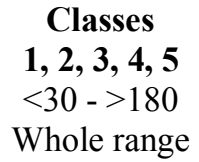 & $\begin{array}{c}\text { Classes } \\
\mathbf{2 , 3 , 4} \\
30-180\end{array}$ \\
\hline $\begin{array}{l}\text { Percentage of } \\
\text { the area }(\%)\end{array}$ & & 14.859 & 19.672 & 37.188 & 23.945 & 4.336 \\
\hline $\begin{array}{c}\text { Area } \\
\text { (Feddan) }\end{array}$ & & 20802.4 & 27540.8 & 52063.0 & 33523.1 & 6070.65 \\
\hline
\end{tabular}


From scenario 1, it can be concluded that, the first three priorities 1, 2 and 3, which represent economic potentials, excellent, very good and good, respectively covered an area of about 100406 Feddan representing approximately $71.719 \%$ of the total study area (140000 Feddan). While, the priority 4 , which represents moderate potentials covered an area of about 33523.1 Feddan representing $23.945 \%$ of the total area. Finally, the priority 5 of poor potential represent $4.336 \%$ covering approximately 6070.65 Feddan and the spatial distribution of the different priorities shown in Fig. (14a) (Scenario 1).

\subsection{Scenario 2}

In this scenario, the aquifer productivity is of prime importance. So, the two layers that represent aquifer productivity take the highest weights; the specific capacity layer ( $40 \%$ out of $100 \%$ of the four layers), and full recovery time layer ( $40 \%$ out of $100 \%$ of the four layers). On the other hand, the depth to the top surface of the Eocene limestone aquifer and the expected dynamic water level calculated at discharge rate of the order $150 \mathrm{~m}^{3} / \mathrm{h}$ take equal weight values of $10 \%$ for each layer. The final model map of this scenario is shown in Fig. (14b), Scenario 2. The characteristics of the areas covering each priority can be summarized in Table (2).

Table (2). Regional characteristics of the areas covering each Priority (Scenario 2).

\begin{tabular}{|c|c|c|c|c|c|c|}
\hline \multirow{3}{*}{ Layer name } & \multirow{3}{*}{$\begin{array}{c}\text { Weight value } \\
(\%)\end{array}$} & \multicolumn{5}{|c|}{ Range of each layer in the final model map } \\
\hline & & Priority 1 & Priority 2 & Priority 3 & Priority 4 & Priority 5 \\
\hline & & Excellent & Very good & Good & Moderate & Poor \\
\hline \multirow{4}{*}{$\begin{array}{l}\text { Depth to limestone } \\
(\mathrm{m})\end{array}$} & \multirow{4}{*}{10} & Classes & Classes & Classes & Classes & Classes \\
\hline & & $2,3,4$ & $1,2,3$ & $2,3,4,5$ & $1,2,3,4,5$ & $1,2,3,4$ \\
\hline & & $150-300$ & $112-250$ & $150-335$ & $112-335$ & $112-300$ \\
\hline & & & & & Whole range & \\
\hline \multirow{4}{*}{$\begin{array}{l}\text { Expected dynamic water } \\
\text { level (m) }\end{array}$} & \multirow{3}{*}{10} & Classes & Classes & Classes & Classes & Classes \\
\hline & & 1,2 & 2,3 & $1,2,3$ & $1,2,3,4,5$ & $2,3,4$ \\
\hline & & $80.5-100$ & $90-110$ & $80.5-110$ & $80.5-127.5$ & $90-120$ \\
\hline & \multirow{3}{*}{40} & Classes & Classes & Class & $\begin{array}{l}\text { Whole range } \\
\text { Classes }\end{array}$ & Class \\
\hline \multirow{2}{*}{$\begin{array}{l}\text { Specific capacity } \\
\qquad\left(\mathrm{m}^{3} / \mathbf{h} / \mathbf{m}\right)\end{array}$} & & 1,2 & 3,4 & 4 & 4,5 & 5 \\
\hline & & $>300-200$ & $200-18$ & $100-18$ & $100-<18$ & $<18$ \\
\hline \multirow{3}{*}{$\begin{array}{c}\text { Full recovery time } \\
(\text { min) }\end{array}$} & \multirow{3}{*}{40} & Class & Class & Classes & Class & Classes \\
\hline & & 1 & 1 & 1,2 & 3 & 4,5 \\
\hline & & $<30$ & $<30$ & $<30-60$ & $60-120$ & $120->180$ \\
\hline \multicolumn{2}{|l|}{ Percentage of the area } & & & & & \\
\hline \multirow{2}{*}{\multicolumn{2}{|c|}{$\begin{array}{l}(\%) \\
\text { Area }\end{array}$}} & 3.612 & 19.354 & 37.79 & 27.135 & 12.109 \\
\hline & & & & & & \\
\hline (Feddan) & & 5057.2 & 27095.0 & 52905.56 & 37989.17 & 16953.03 \\
\hline
\end{tabular}


From scenario 2, also, it can be concluded that, the first three priorities 1,2 and 3, which represent productivity potentials, excellent, very good and good respectively, covered an area of about 85058 Feddan representing approximately $60.756 \%$ of the total study area (140000 Feddan). While, the priority 4 , which represents moderate potentials covered an area of about 37989.17 Feddan representing $27.135 \%$ of the total area. Finally, the priority 5 of poor potential represent $12.109 \%$ covering approximately 16953.03 Feddan and the spatial distribution of the different priorities shown in Fig. (14b) (Scenario 2).

Also, it should be mentioned that the areas of excellent, very good and good potentials (Fig. 14b) have high transmissivity values (1000 to more than $9000 \mathrm{~m}^{2} /$ day, Fig. 11b).

\section{CONCLUSIONS}

From the above-mentioned discussion, the following characteristics of the Eocene fractured limestone aquifer and its potentials in West-West ElMinya area can be concluded as follows:

1. The groundwater flow direction in the aquifer is from east to west and from south to north with some exceptions, where cone of depressions is occurred.

2. The salinity of the groundwater varies from $1000 \mathrm{mg} / \mathrm{l}$ to $2982 \mathrm{mg} / \mathrm{l}$ with dominant salinity value more than $2000 \mathrm{mg} / \mathrm{l}$ covering $96.9 \%$ of the investigated area.

3. The geologic structures have a considerable effect on aquifer productivity due to increasing the fracture systems and caves.

4. The full recovery time ranges between less than $30 \mathrm{~min}$ and more than $180 \mathrm{~min}$.

5. The small values of the full recovery time for the fractured aquifer (Eocene fractured limestone) is attributed to the nature of the karst aquifers which have multiple types of porosity and two flow types of water: laminar and turbulent flows. The laminar flow occurs within the matrix domain of the karst aquifer with slow velocities and the turbulent flow occurs in the large diameter void spaces that are well connected forming conduit domain with high permeability and fast water movement.

6. Geographic Information Systems (GIS) technique was applied as a tool to achieve the target of this study. The final finding of this research work can be used as a guide for the investors with different needs and requirements through two scenarios as follows:

- In case of scenario 1, when the economic factor is the main factor in the process of extracting groundwater, it is preferable to invest in the western and northeastern parts of the investigated area, where these areas have the first three priority classes; 1, 2 and 3, which 
characterized by the excellent, very good and good economic potentials and represent $71.719 \%$ (100406 Feddan) of the total investigated area.

- In case of scenario 2, the high productivity of groundwater is the influencing factor. In this case, the northern half of the study area and the southwestern corner are the promising areas for the investment, where these areas have excellent, very good and good productivity representing $60.756 \%$ ( 85058 Feddan).

\section{REFERENCES}

Abdel Moneim, A.A., J.P. Fernández-Álvarez, E.M. Abu El-Ella and A.M. Masoud (2016). Groundwater management at west El-Minya desert area, Egypt using numerical molding. Journal of Geoscience and Environmental Protection, 4: 66-76.

Andualem, T.G., and G.G. Demeke (2019). Groundwater potential assessment using GIS and remote sensing: A case study of Guna tana landscape, upper Blue Nile Basin, Ethiopia. Journal of Hydrology: Regional Studies, 24: 1-13.

Assaf, H. and M. Saadeh (2008). Geostatistical assessment of groundwater nitrate contamination with reflection on DRASTIC vulnerability assessment: The case of the upper Litani Basin, Lebanon. Water Resources Management, 23 (4): 775-796.

CONOCO (1987). Geologic map of Egypt. Egyptian General Authority for Petroleum (UNESCO joint Map Project), 20 sheets, scale 1:500000, Cairo.

El-Deeb, H., M. El Rawy and E. Habib (2015). Water resources management: case study of El-Minya Governorate, Egypt. International Journal of Scientific and Engineering Research, 6 (6): 48-55.

Elewa, A.M.T., E. El-Sayed, M. El-Kashouty and M. Morsi (2013). Quantitative study of surface and groundwater system in the western part of the River Nile, El-Minya Governorate, Upper Egypt: water quality in relation to anthropogenic activities. Greener Journal of Physical Sciences, 3 (6): 212-228.

Elewa, H.H. and A.A. Qaddah (2011). Groundwater potentiality mapping in the Sinai Peninsula, Egypt, using remote sensing and GISwatershed-based modeling. Hydrogeology Journal, 19 (3): 613-628.

El-Kashouty, M. (2010). Modeling of the limestone aquifer using isotopes, major, and trace elements in the western River Nile between BeniSuef and El-Minya. Fourteenth International Water Technology Conference (IWTC14), Cairo, Egypt, p. 941- 968. 
El-Kashouty, M., E. El-Sayed and A. Kamel (2012). The hydrochemical characteristics and evolution of groundwater and surface water in the western part of the River Nile, El-Minya district, Upper Egypt. International Conference "Transboundary Aquifers": Challenges and New Directions" (ISARM), p. 1-7.

ESRI (2006). ArcMap software version 9.2 (copyright 1999-2006, ESRI, Inc.).

Gedamy, Y., Y. Abdulhady and E. Zaghlool (2019). Hydrochemistry of the Eocene aquifer at the desert fringes of west El-Minya governorate, Egypt. Curr. Sci. Int., 8 (4): 734-763.

Ibrahim, R.G.M. and W.B. Lyons (2017). Assessment of the hydrogeochemical processes affecting groundwater quality in the Eocene limestone aquifer at the desert fringes of El-Minya governorate, Egypt. Aquat Geochem., 23: 33-52.

Ibrahim, S.M.M. (2013). Hydrological evaluation of the tertiary-quaternary aquifer system west Mallawi, Upper Egypt: case study. Egyptian Journal of Geology, 57: 1-30.

Jalludin, M. and M. Razack (2004). Assessment of hydraulic properties of sedimentary and volcanic aquifer systems under arid conditions in the Republic of Djibouti (Horn of Africa). Hydrogeol. J., 12 (2): 159-170.

Korany, E. (1980). Peak runoff calculations and preventing the risk of occasional flooding in Sannur drainage basin, Estern Desert, Beni Suef Governorate, Egypt. $5^{\text {th }}$ Int. Congr. Statist. Comput. Sci., Cairo, p. $505-534$.

Korany, E. (1984). Statistical approach in the assessment of the geohydrologic profiles, 9th Int. Congr. Statist. Comput. Sci. Social and Demogr. Res., Cairo, Ain Shams University Press, p. 161-176.

Korany, E., S. Sakr, M. Darwish and S. Morsy (2008). Hydrogeologic modeling for the assessment of continuous rise of groundwater levels in the quaternary aquifer, Nile Valley, Egypt: Case study. Int. Conf. Geol. Arab World (GAW8), Cairo Univ., p. 703-711.

Magesh, N.S., N. Chandrasekar and J.P. Soundranayagam (2012). Delineation of groundwater potential zones in Theni district, Tamil Nadu, using remote sensing, GIS and MIF techniques. Geoscience Frontiers, 3 (2): 189-196.

Misstear, B.D.R. (2001). The value of simple equilibrium approximations for analyzing pumping test data, Hydrogeology J., 9 (2): 125-126.

Salem, A.A.A. (2015). Hydrogeological studies on the shallow aquifer in the area west Samalot, El-Minya governorate, Egypt. Egyptian Journal of Pure and Applied Science, 53 (4): 49-60.

Sen, Z. (1995). In: "Applied Hydrogeology for Scientists and Engineers". Lewis Publishers, C.R.C. Press, Inco, Florida, USA, 310 p.

Egyptian J. Desert Res., 70, No. 1, 59-82 (2020) 
Shabana, A.R. (2010). Hydrogiological studies on the area West Deir Mouas-Mallawi, El Minia governorate-Egypt. Egypt J. Geol., 54: 61-78.

Summers, W.K. (1972). Specific capacities of wells in crystalline rocks. Groundwater, 10 (6): 37-47.

Tolche, A.D. (2020). Groundwater potential mapping using geospatial techniques: a case study of Dhungeta-Ramis subbasin, Ethiopia. Geology, Ecology, and Landscapes. https://doi.org/10.1080/24749508.2020.1728882.

Verbovsek, T. (2008). Estimation of transmissivity and hydraulic conductivity from specific capacity and specific capacity index in Dolomite aquifers. Journal of Hydrologic Engineering 13 (9): 817823.

Youssef, M.I. (1968). Structural pattern of Egypt and its interpretation. Bull. Amer. Petrol. Geol., 52 (4): 601-614.

Yousif, M., H. Sabet, S. Ghoubachi and A. Aziz (2018). Utilizing the geological data and remote sensing applications for investigation of groundwater occurrences, West El Minia, Western Desert of Egypt, NRIAG Journal of Astronomy and Geophysics, 7 (2): 318-333. 


\section{إمكانيات المياه الجوفية لخزان الحجر الجيري الأيوسيني بمنطقة غرب غرب

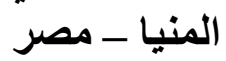

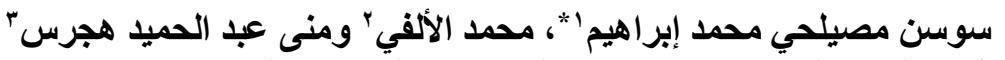

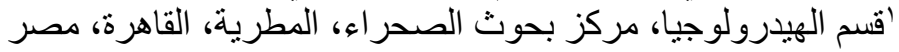

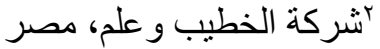

"قام الري و الهيدروليكا، كلية الهندسة ، جامعة عين شمس، القاهرة، مصر

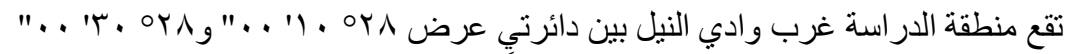

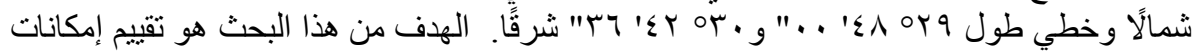

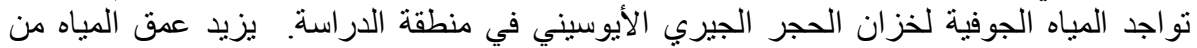

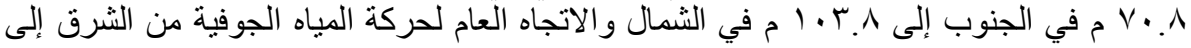

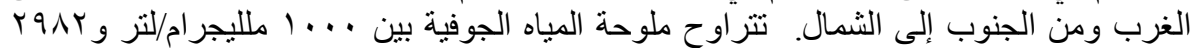

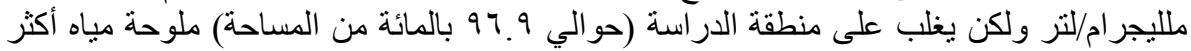

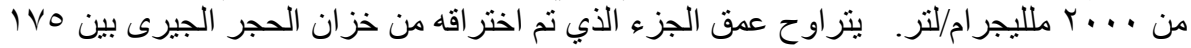

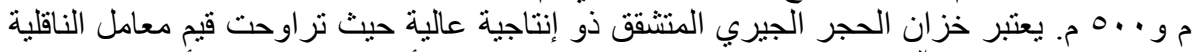

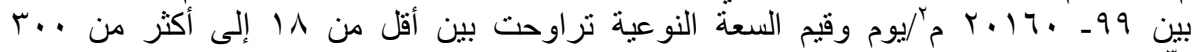

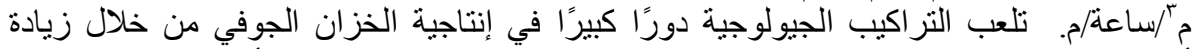

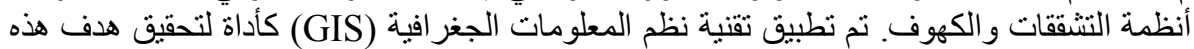

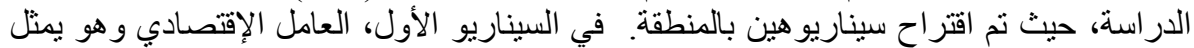

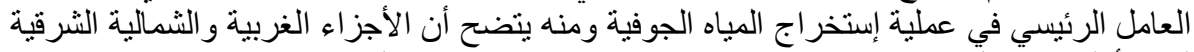

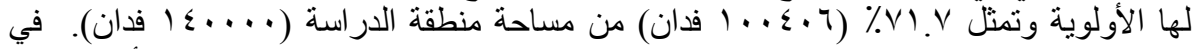

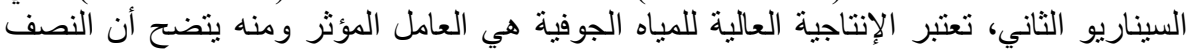

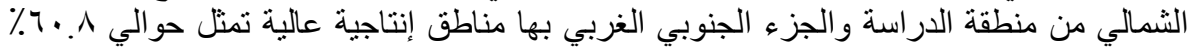
(10.01) فدان) من مساحة منطقة الدراسة.

Egyptian J. Desert Res., 70, No. 1, 59-82 (2020) 